\title{
Rusland har ondt i demokratiet
}

\section{Ljubov Tsukanova}

\section{Vore magthavere lider af sygdommen "etparti-}

system", siger formanden for rådet af direktører i Det Uafhængige Valginstitut, dr.jur. Aleksandr Ivantjenko i dette interview. Han stod i årene 1996-1999 spidsen for Ruslands Centrale Valgkommission

Aleksandr Vladimirovitj, er der en uafhangig valginstitution i Rusland? Ikke som den organisation, hvor De nu arbejder, men som et basalt element $i$ demokratiet?

Der skal meget til, for at der kan blive tale om frie valg i landet. I 1994 blev der gjort et gennembrud, da man vedtog loven om garantier for vælgernes valgrettigheder. Den skabte et system af samarbejde mellem de statslige og offentlige organer, som sikrede borgernes frie meningstilkendegivelse og indeholdt mekanismer, der kunne beskytte mod forfalskning af afstemningsresultaterne.

Partierne og massemedierne skulle fungere som forbindelse mellem samfundet og magthaverne og være magthavernes eksaminatorer. Det var konceptet, og det kom til udtryk i loven. Men dengang mærkede jeg straks, hvilken irritation denne problemstilling fremkaldte: Sådan et system af kommissioner, nogle partier og en slags samfund skal kontrollere os, der er kommet til magten med så stort besvær ...

I Rusland har der jo aldrig været en demokratisk tradition for at komme til magten. Bolsjevikkerne tog den med vold. Hvordan har senere herskere fået magten? Som følge af korridoraftaler og bulldogkamp under tæppet. I Rusland har der aldrig været principper for åbent magtskifte, konkurrence eller politisk kappe- 
strid. Selv Jeltsin greb magten på ikke helt demokratisk vis - han måtte opløse Den Øverste Sovjet (i oktober 1993 - o.a.).

Jeg bør ganske vist i objektivitetens navn sige, at besættelsen af præsidentposten i Rusland ved folkeafstemning var et meget seriøst legitimt grundlag for dannelsen af præsidentmagtinstitutionen. Men denne institution begyndte man at bruge til at kvæle alle andre magtinstitutioner. Parlamentet er endnu ikke kommet sig over den skånselsløse behandling, det var udsat for; der var ikke noget parlament før Jeltsin, og der har heller ikke været noget efter Jeltsin ...

Vores lov om garantier for vælgernes valgrettigheder var faktisk en forfatningslov (en overordnet lov, der udbygger forfatningens principper, fx ombudsmandsloven - o.a.), som dannede grundlag for relationerne mellem de valgte, kontrollerede og åbne myndigheder og så borgerne. Det første forslag handlede om garantier for folkestyre i landet og var en slags dekret om folkestyre.

Men folket i Rusland har aldrig haft nogen magt, og det har det stadig ikke fået. De aktuelle anstrengelser for at opnå noget udelukkende ved hjælp af valgprocedurer er dømt til at mislykkes. Uden frie massemedier, uden professionelle selvstændige politiske partier og uden et uafhængigt system af valgkommissioner er valg i Rusland perspektivløse.
Denne institution er som en kamilleblomst i ørkenen, som ikke får noget vand, ikke passes og ikke støttes.

\section{Demokratidræberne}

De vil dermed sige, at garantierne ikke har fungeret?

Indtil 1999 havde vi held til at modstå presset og undgå større ændringer. Der har altid været lagt pres på valgkommissionssystemet, kraftigst i 1996, da Jeltsins helbred vaklede forud for præsidentvalget, og hele hans hold og inderkreds var frygtelig urolige: Hvad venter der os? Hvad nu, hvad Gud forbyde, hvis der sker noget? Det lignede i øvrigt i høj grad den nuværende situation, hvor holdet også har travlt: Hvad venter der det, hvis der nu kommer en ny præsident?

Men hvorfor frygte, at der kommer en ny præsident i landet? Det er frygteligt, hvis det samme hold forbliver ved magten i landet, og alle principper for folkestyre, som er nedfældet i den gældende forfatning, bliver fuldstændig trådt under fode.

I henhold til den gældende forfatning tilhører magten ikke en gruppe af mennesker, men folket. Men der blev ikke skabt nogle principper for folkestyre i tiden efter vedtagelsen af forfatningen (december 1993 - o.a.) under den første præsident $\mathrm{i}$ Rusland. Og den anden præsident fortsætter tendensen med at lukke alle disse mekanismer ned. Det dre- 
jer sig både om loven om massemedier, loven om politiske partier og om valglovene, lovene om offentlige foreninger og ikke-kommercielle organisationer. Fjernelsen af en hvilken som helst komponent af demokratiet fra denne pakke, fra det politiske system, som var det en del i et urværk, lammer hele systemet.

Folk, der beskæftiger sig professionelt med politik, kan ikke undgå at forstå dette ... Man skal bare holde valg uden modkandidater, som det skete i sovjettiden, og så er de ikke til nogen nytte.

Manglen på professionalisme i politik slår nu alle rekorder. Det postsovjetiske Rusland har ikke kendt til så lav en lovkvalitet på det politiske område, som vi har oplevet de sidste 5-6 år. Det begynder med opbygningen af magtens vertikal: den fuldstændig manglende forståelse af, hvad folk gerne vil regulere. Det er næsten det samme som at reparere bil med en tryklufthammer. Sådan nogle trykluftarbejdere er nu i gang med at udarbejde og vedtage love; de sidder i Dumaen. De har vænnet sig til at gøre honnør og smække hælene sammen; de har aldrig kunnet andet, og de får det heller ikke lært.

Men det er vel professionelle og ikke medlemmerne, der skriver lovene?

Det er højtbetalte lejesoldater. Disse lejemordere er ansat til at udrydde det civile samfunds institutioner, og de får en høj løn for det. Det er ikke kun fysiske personer, men la- boratorier, specialorganer ...

\section{Loven om føreren}

- I sin tid hed det sig, at vi har en sardeles fornuftig valglovgivning, der svarer til de internationale normer. Hvordan har den andret sig, hvad kan den sammenlignes med $i$ dag?

Forfatningen indeholder princippet om et flerpartisystem, ytringsfrihed, møde-, demonstrations- og forsamlingsfrihed. Det står skrevet, at internationale principper og normer er en integreret del af det russiske retssystem, og at hvis interne akter er i modstrid med dem, gælder den internationale rets normer. Men i de sidste 5-6 år er der sket en fuldkommen afmontering af flerpartisystemet. Præsidenten har initieret loven om politiske partier. I virkeligheden bør den kaldes "Loven om partilederen", for den er skrevet til én person.

Vi foreslog en helt anden lov "Om garantier for flerpartisystemet i Den Russiske Føderation”, der tager sit udgangspunkt i forfatningen og ikke er beregnet for én person eller ét parti, men for hele det politiske system. I dette system kunne der være fem, seks, fire, otte osv. politiske partier. Den konceptuelle uoverensstemmelse og den konceptuelle lovændring af forfatningens bestemmelser har ført til, at det er slut med flerpartisystemet i Rusland. På en konkret ordre fra en konkret gruppe af personer, der betjener præsi- 
denten personligt i hans nuværende status.

De ændringer, der er foretaget $\mathrm{i}$ valglovgivningen, har givet valgkommissionerne og domstolene meget farlige instrumenter i hænde: fjernelse af kandidater fra registreringen, afslag på registrering af kandidater, afslag på modtagelse af dokumenter. Hvad har det ført til? Til at de, som det ikke var nødvendigt at registrere, simpelthen ikke blev registreret.

Men hvem fandt det unødvendigt? Selvfølgelig ikke vælgerne, men konkrete personer, der fastholder magten. Vælgerne kommer til valgstederne og kan ikke finde dem, de gerne ville give deres stemme, på stemmesedlerne. Så holder de selvfølgelig op med at gå til disse valg. Der findes ingen anden mekanisme til at trække befolkningen til valgstederne end at give dem tiltrækkende kandidater eller interessante politiske platforme. Der findes Stalins mekanisme, der består i tvang, og den bruges også i dag. Men den var kun rigtig virkningsfuld, når folk blev truet med noget meget alvorligt for ikke at deltage i valgene.

Det var ikke tilfældigt, at de første valg i henhold til Stalins forfatning (af 1936 - o.a.) blev afholdt i slutningen af 1937 efter masseudrensningen af hele det politiske rum, idet udrensningen ikke ramte politiske partier, men fysiske personer, som kunne sige noget fornuftigt. Der skete en udryddelse af hele den elite, der var i stand til tydeligt at artikulere nogle begreber.

Man skammer sig over at sige det, men i løbet af de 100 år siden det første russiske parlament (der sad fra 27.4. til 8.7. 1906 - o.a.) er begrebet opposition ikke blevet nedfældet i juraen. Det er først nu, vi prøver at indføre begrebet fraktion i Statsdumaen. Med hvilket formål, når hele massen af mennesker er en ubrydelig blok til støtte for den siddende præsident? Ordet "parlament" dukkede først op i Jeltsins forfatning i 1993.

Og ved De, hvornår ordet "demokrati” blev nedfældet? I ordforbindelsen "socialistisk demokrati" i forfatningen af 1977. I øvrigt står den nuværende konstruktion af det politiske system, som Putin har skabt, tilbage for den såkaldte forfatning for den udviklede socialisme (Brezjnevforfatningen af 1977 - o.a.) i henseende til holdbarhed og konceptuel systematik.

Noget andet er, at de sovjetiske forfatninger ikke fandt nogen anvendelse. I henhold til forfatningen af 1977 blev der vedtaget en eneste demokratisk lov - "Om folkelig drøftelse af de vigtigste spørgsmål i statsog samfundslivet". Det var den eneste demokratiske lov i hele stagnationsperioden. Men under Putin er der ikke vedtaget en eneste demokratisk lov! Der er vedtaget kontrademokratiske love, der indskrænker folkestyret. Vi har slået en kolbøtte. Men jeg ville nok mene, at det 
ikke er en enkelt persons ansvar. Og dog: Hvis præsidenten forstod nogle ting som civilperson og ikke på militær vis, ville resultatet være et andet. Vore magthavere lider nu af sygdommen "etpartisystem" eller "monopol". En udnævnt embedsmand eller et Dumamedlem, der har fået et mandat, kommer ikke til magten for at realisere det program, vælgerne har brug for. De kommer for at tjene penge.

Kan De huske, med hvilken entusiasme der blev talt om delingen mellem den lovgivende og udøvende magt, om uforeneligheden mellem arbejdet som embedsmand og Dumamedlem og engagement i forretningslivet? Disse konceptuelle ting er for længst glemt, forkastet.

\section{"Magtens parti"}

\section{Men forbuddet er ikke ophavet ved lov?} Det er desavoueret ved loven om tjeneste i staten, ved manglen på en lov om bekæmpelse af korruption. Magthaverne kan ikke vedtage denne lov, vil ikke ligefrem skade sig selv. Præsidenten har i tre år talt måske endda på vores foranledning, for det var os, der udarbejdede denne lov - om nødvendigheden af at vedtage en lov om myndighedernes åbenhed, så borgerne i det mindste kunne få fat i myndighedernes beslutninger. Den har de ikke kunnet vedtage i tre år. Magthaverne er stadig ved at høvle den til efter eget forgodtbefindende.
Jeg blev meget bekymret over det sidste forsøg på at indskrænke demokratiet - de nye bestemmelser i lovgivningen om offentlige foreninger og ikkekommercielle organisationer. Det er toppen af uprofessionalisme i ændringerne og toppen af kynisme i den måde, de er blevet presset igennem på. Man har lejet de samme mordere til at gøre det af med et helt segment af det politiske system. Det er uantageligt for en professionel. Men vi har en hel del mennesker, der med glæde tager sig af den slags lægebistand, der i virkeligheden er en ombringelse af det politiske demokrati, intet mindre.

Det er desværre også en bebrejdelse, der er rettet mod de politiske partier. Nomenklaturaen har samlet sig i "magtens parti" - en ny udgave af Sovjetunionens Kommunistiske Parti; det nye arbejder på samme måde som det gamle. Men der er heller ikke vokset andre partier frem. Alle de mere eller mindre kendte partier er i lige så høj grad partier omkring en fører; førerne er blot forskellige.

Jeg mener, at det gennemførte komplot mellem de politiske eliter i praksis har ført til et forbud mod politisk virksomhed, en selvbegrænsning af selv samme eliter. De tilintetgør sig selv. Det var det samme, der skete i landet efter bolsjevikkernes revolutionære magtovertagelse: De satte alle selvstændigt tænkende på dampere eller smed dem ud af Rusland, eller også fratog de dem deres 
levnedsmiddelration. Nu er det glemt, at alle personer, der fik frataget deres stemmeret, også blev undertrykt socialt: De fik ganske enkelt ikke nogen rationeringskort. Disse folk havde ingen anden udvej end at $\mathrm{d} \varnothing$ af sult eller flygte. Og det var mennesker, der kunne tænke, analysere og opponere mod magthaverne.

Et klogt menneske opponerer altid, et dumt erklærer sig altid enigt.

\section{Bureaukratisk magtmonopol}

\section{Hvorfor garanterer loven om garantier} for valgrettigheder egentlig ikke noget? Hvorfor garanterer love $i$ det hele taget ikke noget?

I loven om garantierne har vi prøvet at gøre borgeren til hovedpersonen i den politiske proces på grundlag af den gældende forfatning. Vi lever jo i en republik, og $\mathrm{i}$ en republik er hovedpersonen ikke et parti, ikke præsidenten, ikke de udpegede statholdere - guvernørerne. Hovedpersonen er borgeren. $\mathrm{Og}$ han skal have et fuldstændigt instrumentarium, hvormed han i givet fald kan drage præsidenten eller guvernøren til ansvar. Derfor fastlægges den grundidé, at netop borgerne er de vigtigste deltagere i valgene.

Men vi er stødt på kraftig modstand i de selv samme politiske lederpartier. De ville gerne være de vigtigste subjekter i valgprocessen. Da Jeltsin bragte partirepræsentationen i Dumaen op til halvdelen, var det under vores forhold et forræderi mod borgernes rettigheder og en indrømmelse til bureaukratiet, som straks skar halvdelen af folkestyrelagkagen (if. 1993-forfatningen vælges 225 medlemmer på partilister, og 225 i enkeltmandskredse - o.a.). Partierne fik også ret til at opstille kandidater i enkeltmandskredsene. Dumapartierne fritog sig selv for at samle underskrifter og gjorde deres adgang til æteren lettere. Og nu er magten i landet praktisk talt monopoliseret, dog ikke af partierne, de er udbrændt ... Magten er monopoliseret af bureaukratiet.

Derfor kunne den lov allerede i 1999 ikke længere kaldes en lov om vælgernes valgrettigheder. Den var blevet til en lov om garantier for fire politiske partier. Og i dag giver den heller ikke dem nogen garantier. Denne lov giver alle garantier til én vælger, som i sin skikkelse har forenet både den aktive og den passive valgret. Derfor er der opstået en mærkværdig konstruktion, det såkaldt suveræne demokrati. Jeg har beskæftiget mig med spørgsmål vedrørende demokrati i 30 år, men de eksperter, som har udarbejdet konceptet om det såkaldt suveræne demokrati, har jeg hidtil ikke kendt til.

Hvad kan denne model sammenlignes med på verdensplan?

Den kan sammenlignes med vores egne russiske erfaringer. Det er pigtråd. Sådan var det såkaldt proletariske demokrati med koncentrationslejrene. 
Jeg må insistere på, at uden et reelt flerpartisystem, uden uafhængige massemedier, uden frihed til dannelse af offentlige foreninger har borgerne i vores land ingen muligheder for at påvirke magthaverne hvert fjerde år, når de skal vælge dem. Det er vores ulykke.

Vi er stadig ideologiske, metodologiske gidsler for de kolossale fejl, der blev begået for 100 år siden og dernæst gentaget og gentaget, og hver generation har ydet sit bidrag til at akkumulere de omkostninger, der nu sætter deres præg på befolkningen og landet som helhed. Landet er ved at blive kvalt under byrden af de synder, den russiske politiske klasse har begået. Det drejer sig også om førrevolutionære personer; Nikolaj den Anden fik nervøse trækninger af ordet "parlament". Det er velkendt, hvad det endte med.

\section{Kalkerede valg}

Er valgene i regionerne en tro kopi af det føderale system?

Absolut. Hvori består i øvrigt den kolossale fare for det russiske statssystem? I at vi er slået ind på at gøre den føderale lovgivning ensartet. Vi lever i en føderation. Rusland er i demografisk henseende et land med store forskelle. Vælgernes mentalitet, fx i Det Fjerne Østen, hvor der har været fangelejre, hvor folk blev gennet hen og efter hårde prøvelser blev boende, den mentalitet er helt anderledes. Dér er folk forenet for at overleve, de udstøder tilflyttere, de er meget selvstændige, og det er en dumhed uden lige at prakke disse mennesker valglove på, der er kalkeret fra det føderale center.

Amerikanerne har også koloniseret Amerika, men de har været kloge nok til at bevare valglovgivningens føderalistiske natur. Vi har lagt vores føderationssubjekter (de 89 regioner - o.a.) på prokrustessengen uden at tage hensyn til sædvanerne hos den befolkning, der bor i Det Fjerne Østen, i Sibirien eller i Nordkaukasus.

Nu er der valgkamp i Moskva, der er hældt enorme offentlige midler i reklame (valget til Moskva Byduma fandt sted 4.12.05- o.a.). Men det er en primitiv reklame. Statens penge går til tomme opfordringer: tænk dig om, tænk dig om. Men hvem skal man tænke på? Hvad skal man tænke på? Det gives der ikke nogen fornuftig forklaring på. Hvilke partier deltager? Hvilke ledere står på listerne? På tv ser vi ét parti, det noksom bekendte (Forenet Rusland, der støtter Putin - o.a.). Vi driver folk op i et hjørne. De kloge går ikke hen og stemmer, og pensionisterne ved i forvejen, hvem de skal stemme på.

Det siges ikke desto mindre, at valget $i$ Moskva er forskelligt fra de andre.

Moskvas valglov adskiller sig på ingen måde fra den føderale. Det er for $85 \%$ vedkommende en kalke af den føderale lovgivning med alle tilhørende omkostninger. Scenariet 
for afholdelsen af valget adskiller sig heller ikke på nogen måde. Det er ét parti, der får de reelle chancer ifølge dette valgsystem. Det er det såkaldt forvrænget-proportionale valgsystem, der er indført. Hvordan man end stemmer, så giver det det resultat, som magthaverne har bestemt på forhånd.

Hvilken "vegt" har Moskvas Byduma?

Jeg mener, at deputeretkorpsets vægtfylde er yderst ringe. Tag borgmesterkontoret! Det er et konglomerat af embedsmænd, mens der kun er 35 medlemmer af Moskvas Byduma. Det er uforenelige størrelser. Kommensurabilitetsprincippet er ikke overholdt. Det er klart, hvem der reelt fastlægger politikken.

Moskva kunne selvfølgelig skille sig en smule ud på baggrund af andre lovgivende forsamlinger, hvis man var fornuftig nok til at få trefire partier ind i Bydumaen, lave regler for deres arbejde, eventuelt vedtage en lov om Moskva Byduma, som kunne sikre mindretallets rettigheder, oppositionens rettigheder, indføre parlamentarisk kontrol og styrke medlemmernes indflydelse på udnævnelser i administrationen.

I Moskva er der trods alt bevaret mere elite, der er flere tænkende og forstående mennesker, her kunne man lave modeller, som siden kunne udføres til andre regioner. Modeller for opbygning af parlamentet som en gren af magten, der skulle bremse monopolistiske bestræbelser og kontrollere den udøvende magt.

Men med det format, med det antal og med de resurser, der nu er tale om, kan parlamentet ikke konkurrere med den.

Interviewet stod $i$ det russiske tidsskrift Novoje Vremja (Ny Tid) nr. 48/2005 Oversat fra russisk af Lars P. PoulsenHansen 